\author{
Beata Dubiel \\ Uniwersytet Ekonomiczny w Katowicach \\ e-mail: beata.dubiel@ue.katowice.pl
}

\title{
ROLA TERENÓW ZIELONYCH \\ W ZRÓWNOWAŻONYM ROZWOJU MIAST \\ W WOJ. ŚLĄSKIM
}

\section{THE ROLE OF GREEN AREAS \\ IN SUSTAINABLE URBAN DEVELOPMENT \\ IN THE PROVINCE OF SILESIA}

\author{
DOI: $10.15611 /$ pn.2018.527.03 \\ JEL Classification: Q50
}

\begin{abstract}
Streszczenie: Obecność terenów zieleni miejskiej w mieście ma niewątpliwie znaczący wpływ na jego zrównoważony rozwój. Zieleń spełnia kluczową rolę w aspektach ekologicznym, środowiskowym, estetycznym, a przede wszystkim społecznym. Dbałość o tereny zielone w Polsce niestety nie jest na dostatecznie wysokim poziomie. Władze samorząów nie dostrzegają problemów związanych z należytym utrzymaniem oraz odnawianiem, pielęgnowaniem i poszerzaniem terenów zielonych. Zadania z zakresu ochrony przyrody są często odsuwane na dalszy plan, zarówno pod względem nakładów finansowych, jak i rzeczowych. Celem artykułu jest zaprezentowanie oraz analiza roli zielonych ekosystemów ze szczególnym uwzględnieniem korzyści pozyskiwanych z terenów zielonych w aspekcie zrównoważonego rozwoju obszarów miejskich. Zastosowane metody badawcze opierają się na studiach literatury z badanego zakresu oraz analizie wyników badań ankietowych przeprowadzonych wśród gmin województwa śląskiego oraz wśród mieszkańców tego regionu.
\end{abstract}

Słowa kluczowe: zrównoważony rozwój, tereny zielone, polityka ekologiczna.

Summary: The presence of urban green areas in the sustainable development of the city undoubtedly has a significant impact on its development. Greenery plays a key role in the ecological, environmental, aesthetic and above all social aspect. The care for green areas in Poland is unfortunately not at a sufficiently high level. The authorities of cities, communes and provinces do not notice problems related to proper maintenance and renovation, cultivating and broadening of green areas. Tasks in the field of nature conservation are often postponed to the background, both in terms of financial and material respect. The aim of the article is to present and to analyse ecosystem services, with particular reference to the benefits derived from green areas, in the context of sustainable development of urban areas. The applied research methods are based on the study of literature from the tested range, analysis of the results of surveys conducted among the municipalities of the province of Silesia and among the inhabitants of the region.

Keywords: sustainable development, green areas, ecological policy. 


\section{Wstęp}

Miasta są wytworem rozwoju cywilizacyjnego człowieka, ich populacja, infrastruktura naziemna i podziemna stanowią układ ekologiczny strukturalno-funkcjonalny, w którego obrębie dochodzi do przepływu energii i obiegu materii. Jest to pewnego rodzaju system otwarty, którego funkcjonowanie uzależnione jest od decyzji człowieka. Czynnik antropogeniczny w połączeniu z częścią przyrodniczą tworzą system działający zgodnie z potrzebami człowieka.

Człowiek w odróżnieniu od innych gatunków egzystujących w ekosystemach potrafi w świadomy sposób przekształcać środowisko. Zamiast czerpać pożywienie, wodę i energię z lokalnych zasobów przyrody, może sprowadzić je z odległych terenów. Poza zaspokojeniem podstawowych potrzeb człowieka zasoby środowiska mają również inną, bardzo istotną właściwość. Przyroda, zieleń wpływa na jakość warunków życia ludności, nie tylko poprawiając wizerunek miasta, ale również wpływając pozytywnie na psychikę mieszkańców. Ludzie czują się emocjonalnie związani z zielenią, dlatego starają się ją wzbogacać i pielęgnować. Niestety dochodzi również do sytuacji, gdy człowiek degraduje i niszczy zieleń, doprowadzając w skrajnych przypadkach do katastrofy ekologicznej.

W artykule podjęto próbę oceny roli, jaką pełnią tereny zielone w zrównoważonym gospodarowaniu miastem na przykładzie województwa śląskiego. Zaprezentowane zostaną wyniki badań pierwotnych, które obejmowały:

- badania ankietowe przeprowadzone w roku 2014, dotyczące rozwoju rynku dóbr i usług ekologicznych w województwie (ankieta skierowana do wszystkich 167 gmin województwa, zwrot 70 gmin);

- badania ankietowe przeprowadzone w roku 2017, dotyczące zrównoważonego rozwoju gmin (ankieta skierowana do wszystkich 167 gmin województwa, zwrot 81 gmin);

- badania ankietowe wśród mieszkańców województwa śląskiego w latach 2014 i 2017 (ankiety skierowane do 1000 gospodarstw domowych, zwrot ok. 500 ankiet w każdym badaniu). W badaniach ankietowych założono prosty dobór losowy próby i zrealizowano je za pomocą ankiety rozdawanej na obszarze gmin województwa śląskiego.

Badania ankietowe były przeprowadzone w ramach:

- potencjału badawczego Katedry Zarządzania Ochroną Środowiska Uniwersytetu Ekonomicznego w Katowicach w 2015 roku,

- potencjału badawczego Katedry Gospodarki Przestrzennej i Środowiskowej Uniwersytetu Ekonomicznego w Katowicach w 2017 roku.

Część zadanych pytań w ankietach dotyczyła kwestii ochrony terenów zielonych i bioróżnorodności w miastach. 


\section{Funkcje zieleni w mieście}

Koncepcja zrównoważonego rozwoju w odniesieniu do przestrzeni publicznej znalazła odzwierciedlenie w Nowej Karcie Ateńskiej. Zgodnie z treścią dokumentu planowanie przestrzenne ma żywotne znaczenie przy kreowaniu zrównoważonego i trwałego rozwoju oraz służy rozważnemu gospodarowaniu przestrzenią, będącą podstawowym, ale ograniczonym w wielkości zasobem naturalnym, zapotrzebowanie na który ustawicznie wzrasta [Nowa Karta Ateńska 2003]. Propagowaną wizją jest miasto spójne, które odpowiada potrzebom teraźniejszości i przyszłości. Pod pojęciem spójności przedstawiono spójność w wymiarach społecznym, ekonomicznym, środowiskowym i przestrzennym.

Występowanie terenów zieleni miejskiej w zrównoważonym rozwoju miasta ma niewątpliwie znaczący wpływ na jego rozwój. Zieleń spełnia kluczową rolę w aspektach ekologicznym, środowiskowym, estetycznym, ale i technicznym, społecznym.

O społecznych funkcjach zieleni decydują jej następujące cechy:

- zieleń w charakterze miejsca rekreacji, np. boiska, place zabaw, ścieżki rowerowe itp.,

- zieleń jako przestrzeń publiczna, miejsce spędzania wolnego czasu, wypoczyn$\mathrm{ku}$, spotkań oraz integracji społecznej,

- zieleń - miejsce ucieczki od zgiełku, hałasu miasta, miejsce wyciszenia,

- zieleń postrzegana jako miejsce rozwoju kultury, imprez masowych, koncertów, pikników,

- zieleń jako miejsce dla każdego, dla rodzin, dzieci, młodzieży, seniorów,

- zieleń to obszar edukacji, poznawania fauny i flory,

- zieleń w charakterze towarzysza pieszych, np. zielone chodniki, ciągi dla pieszych, rowerzystów,

- zieleń jako regulator, barometr zdrowia, nastroju oraz rozwoju fizycznego.

Środowiskowe, ekologiczne znaczenie przyrody w mieście można ująć następująco:

- zieleń miejska jest formą ochrony przyrody w mieście, bioróżnorodności,

- zieleń wpływa na wzrost odpowiedzialności za jakość środowiska wśród społeczeństwa,

- zieleń miejska jest często miejscem poznawania nowych gatunków roślin, np. ogrody botaniczne lub zwierząt, np. ogrody zoologiczne, oraz ich ochrony,

- zieleń redukuje wahania temperatury w mieście, np. zieleń przyuliczna,

- zieleń miejska produkuje tlen, wpływa na klimat, zmniejsza zanieczyszczenie oraz ogranicza prędkość wiatru.

Tereny zielone spełniają w mieście także role estetyczne, można je ująć jako:

- zieleń tworzy harmonię z obiektami architektury, dobrze zaprojektowana perfekcyjnie komponuje się z nimi, 
- zieleń stanowi wizytówkę miasta, np. parki, ogrody, wpływa na estetyczną percepcję miasta wśród mieszkańców oraz przyjezdnych,

- zieleń stanowi ozdobę dla szarości w mieście, łamie stereotyp miejskiego życia,

- zieleń wpływa na oryginalność danej ulicy, jezdni, zmienia jej wizerunek i zewnętrzny odbiór na spokojniejszy, niepowtarzalny,

- zieleń odgrywa kluczową rolę w tworzeniu, rozwoju i zachowaniu ładu przestrzennego w mieście.

Wskazać należy także na istotne techniczne funkcje miejskiej przyrody, takie jak:

- ochrona przed powodzią, śniegiem, lodem,

- redukcja siły wiatru, ochrona przeciwwietrzna,

- ochrona przed nasłonecznieniem, np. parkingi, place, chodniki,

- redukcja hałasu w mieście,

- izolowanie terenów przemysłowych, ciągów komunikacyjnych, kolejowych od stref mieszkalnych.

W kontekście ochrony ekosystemów i zrównoważonego rozwoju obszarów miejskich bardzo istotnym wyzwaniem jest właściwy sposób prowadzenia przez władze publiczne planowania przestrzennego, a szczególnie lokalizacja i struktura zieleni, która ma istotne znaczenie dla jakości powietrza. Degradacja terenów zielonych w mieście wpływa na pogarszanie się jakości powietrza, a wraz z nim - jakości życia [Lorek 2015]. Jakość życia w mieście jest uzależniona m.in. od warunków przyrodniczych, jakimi dysponuje miasto, ale także od ekosystemów, które to miasto otaczają, stanowią zewnętrzny pierścień, dostarczają wielorakich usług mieszkańcom. Ekosystemy zlokalizowane w bliższej lub dalszej okolicy miasta służą jako zaplecze rekreacyjne, filtr powietrza, dostawca żywności oraz wody pitnej dla mieszkańców miasta.

Wartość uznawana jest za podstawową kategorię ekonomiczną. Do niedawna ekonomiści interesowali się wyłącznie wartością użytkową, czyli korzyścią uzyskiwaną poprzez pośrednie lub bezpośrednie użytkowanie dóbr, nie dostrzegając wartości pozaużytkowej, przyjmującej z reguły postać satysfakcji z występowania danej korzyści. Zdawano sobie sprawę z istnienia innej wartości, ale w związku z tym, że nie występowała ona w transakcji rynkowej, jej znaczenie było bagatelizowane. Usługi dostarczane przez zieleń przyjmują postać dóbr publicznych - takich, z których korzystają wszyscy mieszkańcy miasta i są rozpatrywane zarówno w kategorii wartości użytkowej, jak i pozaużytkowej. W związku z tym, gdy chce się dokonać wyceny wartości przyrody w mieście, kluczowa jest interwencja administracji, której zadaniem będzie rozpoznanie ilościowe dobra na społecznie optymalnym poziomie. Polega to na oszacowaniu kosztów i korzyści, a następnie wyborze odpowiedniego rozwiązania maksymalizującego korzyści społeczne [Giergiczny, Kronenberg 2012]. 


\subsection{Klasyfikacja zieleni miejskiej}

W literaturze fachowej można odnaleźć wiele definicji pojęcia terenów zielonych oraz prób dokonania ich klasyfikacji. Ogólnie zieleń miejską można ująć w sposób interdyscyplinarny i podzielić na 5 grup użytkowych:

- zieleń ogólnodostępna - parki miejskie i dzielnicowe, zieleńce, parki kultury i wypoczynku, parki centralne, zieleń uliczna, promenady, bulwary, lasy komunalne, lasy podmiejskie, zieleń izolacyjna;

- zieleń o ograniczonym dostępie - ogrody botaniczne, ogrody zoologiczne, ogrody etnograficzne, ogrody działkowe, cmentarze, parki i ogrody zabytkowe;

- zieleń towarzysząca - przedogródki, ogrody domowe, place zabaw, zieleń towarzysząca budynkom oświaty, zieleń towarzysząca obiektom kulturalno-społecznym, administracyjnym, służby zdrowia, zieleń przy obiektach sakralnych;

- zieleń występująca na terenach produkcyjnych - obszary gospodarki leśnej, rolnej i ogrodniczej,

- zieleń wycieczkowo-wypoczynkowa - ośrodki wypoczynkowe, parki narodowe i krajobrazowe, agroturystyka.

\section{Ocena terenów zielonych w miastach śląskich z perspektywy mieszkańców}

Badania empiryczne przeprowadzono wśród grupy reprezentatywnej mieszkańców woj. śląskiego w latach 2014 i 2017. W ankiecie badawczej zadano pytania o stan obszarów zielonych w gminie, ich ilość, poziom zalesienia, przejawy degradacji zasobów roślinnych i zwierzęcych. Ponad połowa respondentów oceniła stan obszarów zielonych w swojej gminie jako średni (49,1\% w 2014 r. i 54,2\% w 2017 r.), niewielka grupa (10\% w 2014 r. i 21\% w 2017 r.) uznała poziom zieleni miejskiej za dobry, natomiast ok. 35\% w 2014 r. i tylko 12\% w 2017 r. ankietowanych wskazało na niezadowalającą jakość miejskich terenów zielonych, pozostali ankietowani nie zwracają uwagi na ten problem. $Z$ analizy danych wynika, iż w powtórzonym w 2017 roku badaniu wyraźnie zmalała o 23\% liczba respondentów uznających stan zieleni za zły, niezadowalający. Oznaczać to może, iż w gminach nastąpiła poprawa w zakresie utrzymania terenów zielonych, dokonano też znacznych nasadzeń. Trzecia część ankietowanych (podobnie w każdym badaniu) uważa, iż areał miejskich terenów zielonych jest ubogi, niewystarczający w stosunku do potrzeb mieszkańców. Konsumenci zauważają potrzebę zwiększania przestrzeni zielonych w centrach miast, ale i na obrzeżach, osiedlach mieszkaniowych. Wskazują przy tym głównie na funkcje estetyczne, rekreacyjne, zdrowotne oraz ekologiczne zielonych ekosystemów.

Badanie przeprowadzone w 2017 roku pozwoliło respondentom wskazać najistotniejsze funkcje, jakie w ich ocenie spełniają miejskie tereny zielone. Ankietowani mieli możliwość oznaczyć maksymalnie trzy funkcje. Rozkład odpowiedzi wygląda następująco: 
- oczyszczanie powietrza - 82\% wskazań,

- oczyszczanie wody - 49\% wskazań,

- miejsca życia roślin i zwierząt - 46\% wskazań,

- miejsce wypoczynku i rekreacji - 41\% wskazań,

- ochrona przed hałasem - 22\% wskazań,

- $\quad$ stabilizacja klimatu - 20\% wskazań,

- ochrona przed powodzią - 15\% wskazań,

- regulacja temperatury - 10\% wskazań.

Respondenci zostali poproszeni o wskazanie głównych symptomów degradacji zasobów roślinnych i zwierzęcych, występujących na terenach zamieszkałych. Wskazywane przejawy to:

- $\quad$ nieuzasadniona wycinka drzew, lasów (37\% w 2014 r. i 49\% w 2017 r.),

- usychanie, zamieranie drzew i krzewów, choroby drzewostanów (35\% w 2014 r. i $36 \%$ w 2017 r.),

- zanik i zmniejszanie liczebności gatunków roślin (26\% w 2014 r. i 24\% w 2017 r.),

- zanik i zmniejszanie liczebności gatunków zwierząt (22\% w 2014 r. i 18\% w 2017 r.),

- inne, np.: zaśmiecanie terenów zielonych, kłusownictwo, brak zieleni w otoczeniu (10\% w 2014 r. i 3\% w 2017 r. $)^{1}$.

Ankietowani mieszkańcy wskazali także na źródła oraz przyczyny degradacji terenów zielonych. W opiniach dominowały zmiany i wpływ antropopresji na przyrodę. Szczegółowy rozkład odpowiedzi prezentuje tabela 1.

Tabela 1. Źródła degradacji ekosystemów roślinnych i zwierzęcych w gminach woj. śląskiego*

\begin{tabular}{|l|c|c|}
\hline \multicolumn{1}{|c|}{ Źródła degradacji } & $\begin{array}{c}\text { Udział odpowiedzi } \\
\text { w } 2014 \mathrm{r} .\end{array}$ & $\begin{array}{c}\text { Udział odpowiedzi } \\
\text { w } 2017 \mathrm{r} .\end{array}$ \\
\hline Zaśmiecanie, dzikie wysypiska śmieci & $60 \%$ & $65 \%$ \\
\hline Zanieczyszczenie powietrza & $58 \%$ & $93 \%$ \\
\hline $\begin{array}{l}\text { Dewastacja przez człowieka (niszczenie, quady } \\
\text { i motory na terenach leśnych) }\end{array}$ & $37 \%$ & $52 \%$ \\
\hline Szkody górnicze & $35 \%$ & $45 \%$ \\
\hline $\begin{array}{l}\text { Zanieczyszczenie wód powierzchniowych } \\
\text { i podziemnych }\end{array}$ & $30 \%$ & $46 \%$ \\
\hline $\begin{array}{l}\text { Zajmowanie terenów zielonych przez budownic- } \\
\text { two (intensywne procesy urbanizacyjne) }\end{array}$ & $26 \%$ & $35 \%$ \\
\hline Budowa nowych dróg, rozwój komunikacji & $23 \%$ & $22 \%$ \\
\hline Zbyt intensywny wyrąb lasu & $15 \%$ & $20 \%$ \\
\hline Nadmierna chemizacja i intensyfikacja rolnictwa & $13 \%$ & $18 \%$ \\
\hline Kłusownictwo & $4 \%$ & $6 \%$ \\
\hline Zbyt intensywny odłów zwierzyny & $3 \%$ & $5 \%$ \\
\hline Nadmierne użytkowanie turystyczne & $3 \%$ & $8 \%$ \\
\hline
\end{tabular}

* Liczby nie sumują się do 100\%, gdyż możliwe było wybranie więcej niż jednej odpowiedzi.

Źródło: opracowanie własne na podstawie wyników badań ankietowych.

1 Liczby nie sumują się do 100\%, gdyż możliwe było wybranie więcej niż jednej odpowiedzi. 
Analiza wyników badań wskazuje, iż w 2017 roku największe znaczenie wśród źródeł degradacji ekosystemów zielonych i zwierzęcych miało zanieczyszczenie powietrza. Można uznać, iż respondenci uznali smog za potencjalne zagrożenie dla bytności fauny i flory w miastach województwa śląskiego. Mieszkańcy w przeważającej większości (68\% wskazań) uznali, że degradacja szaty roślinnej wpływa niekorzystnie na jakość życia społeczeństwa. Niewiele, bo $12 \%$ ankietowanych, nie dostrzega takiego problemu, a 20\% nie ma wiedzy czy też świadomości w tym zakresie.

\section{Ocena terenów zielonych w miastach śląskich z perspektywy gmin}

Dbałość o tereny zielone w Polsce niestety nie jest na dostatecznie wysokim poziomie. Władze samorządów terytorialnych nie dostrzegają problemów związanych z należytym utrzymaniem oraz odnawianiem, pielęgnowaniem i poszerzaniem terenów zielonych. Zadania z zakresu ochrony przyrody są często odsuwane na dalszy plan, zarówno pod względem nakładów finansowych, jak i rzeczowych. Samorządy wykazują się większą dbałością o stan wód, odprowadzanie i oczyszczanie ścieków, gospodarkę odpadami i zaspokajanie innych potrzeb mieszkańców, jednocześnie bagatelizując jakość zieleni miejskiej. Większość ankietowanych gmin uznała ochronę i utrzymanie terenów zielonych za ważne zadanie, ale realizowane w dalszej kolejności. Tylko jedna $\mathrm{z}$ badanych gmin wskazała jako priorytetową ważność dbałość o zieleń miejską.

W ankiecie skierowanej do gmin w 2017 roku została poruszona kwestia wskazania najistotniejszych problemów ekologicznych występujących na obszarach samorządów. Większość ankietowanych gmin stwierdziła, że głównymi problemami na ich obszarze są:

- niska emisja z domów mieszkalnych (80\% gmin),

- zanieczyszczenia wynikające z dużego natężenia ruchu komunikacyjnego (37\% gmin),

- zaśmiecanie oraz dzikie wysypiska odpadów komunalnych (30\% gmin).

Badane samorządy najczęściej oceniały poziom prowadzonych inicjatyw w zakresie ochrony i utrzymania terenów zieleni jako średnio zaawansowany $(63 \%$ w 2014 r. i 61\% w 2017 r.). W roku 2017 wzrosła znacznie liczba gmin określających działania w ochronie zieleni jako bardzo zaawansowane (26\% odpowiedzi). Odmiennie przedstawia się sytuacja w zakresie ochrony przyrody i bioróżnorodności. W 2014 roku gminy najczęściej stwierdzały brak działań (ok. 30\%), w 2017 roku brak działań potwierdziło $20,5 \%$ ankietowanych samorządów, a gminy najczęściej wskazywały zaawansowanie działań w tym zakresie na poziomie średnim (ok. 42\% ankietowanych gmin). W roku 2017 zapytano dodatkowo o konkretne obszary, w których są realizowane różnego rodzaju projekty (inwestycyjne, edukacyjne, do- 
tyczące wyceny itp.) na terenie gminy. Aktywność gmin w obszarach związanych z ochroną obszarów zielonych i bioróżnorodności można ocenić jako niską.

Realizację zadań inwestycyjnych w zakresie utrzymania terenów zielonych deklaruje większość ankietowanych gmin (w 2017 r. 52\% gmin realizowało takie inwestycje, $14 \%$ zakończyło proces inwestycyjny, ok. 34\% gmin planuje podjęcie inwestycji), co stanowi postęp w porównaniu z rokiem 2014.

Głównym źródłem finansowania zadań inwestycyjnych z ochrony przyrody są środki własne samorządów (ok. 50-65\%) lub fundusze unijne (10-25\%). Około 10$-20 \%$ środków inwestycyjnych pochodziło z Narodowego Funduszu Ochrony Środowiska i Gospodarki Wodnej lub Wojewódzkiego Funduszu Ochrony Środowiska i Gospodarki Wodnej.

\section{Zakończenie}

Wyniki badań pozwalają sądzić, iż zieleń miejska dla społeczeństwa woj. śląskiego jest kluczowa i znacząca. Oprócz rekreacji, wyciszenia oraz wpływu na zdrowie mieszkańcy są świadomi funkcji dydaktycznej oraz wpływu na integrację społeczeństwa. Dzięki zieleni miejskiej mieszkańcy, którzy nie posiadają własnego ogródka lub działki rekreacyjnej, mogą obcować z przyrodą ogólnodostępną i czerpać z niej korzyści. Mieszkańcy postrzegają i wskazują zapotrzebowanie na większą ochronę przyrody, zarówno w aspekcie społecznym, jak i ekonomicznym. Niestety nieco odmienne podejście do ochrony terenów zielonych wykazują włodarze miast. Samorządy gminne często nie dostrzegają potrzeby zachowania odpowiedniego areału obszarów zielonych i konieczności ochrony przyrody w miastach. W wielu polskich miastach przyroda i zieleń są nawet postrzegane jako bariera rozwoju nowych inwestycji, a władze miejskie odchodzą od systemowego spojrzenia na tereny zielone.

Tendencje występujące w krajach rozwiniętych wskazują na wysoką wartość wyceny usług ekosystemów w zrównoważonym rozwoju miast. Wyniki ekonomiczne takiej wyceny mają wpływ na podejmowane decyzje administracyjne oraz inwestycyjne realizowane w samorządach. Szczególną uwagę zwraca się na zachowanie i rozwijanie bioróżnorodności, uniwersalność oraz edukację ekologiczną terenów zielonych.

W Polsce samorządy często postrzegają przyrodę, zieleń miejską jako barierę rozwoju inwestycji, zwłaszcza liniowych. Należy dążyć do zmiany takiego podejścia oraz promować rozwój inwestycji łączących zachowanie obecnego stanu przyrody lub inwestycji poprawiających jakość terenów zielonych w miastach. 


\section{Literatura}

Giergiczny M., Kronenberg J., 2012, Jak wycenić wartość przyrody w mieście? Wycena drzew przyulicznych w centrum Łodzi, Zrównoważony Rozwój Zastosowania, nr 3, red. J. Kronenberg, Fundacja Sendzimira, Kraków, s. 74.

Gray R., Owen D., Sopher M.J., 1998, Setting up a control system for your organization, Nonprofit World, vol. 16, no. 3, s. 65-76.

Kołodko G., 2010, Neoliberalizm i światowy kryzys gospodarczy, Ekonomista, nr 1, s. 23-30.

Kowalski J. (red.), 2013, Rola polityki logistycznej, Wydawnictwo Uniwersytetu Ekonomicznego we Wrocławiu, Wrocław.

Kowalski T., Nowak T., Pisarek W. (red.), 2003, Aspekty zarządzania, Wydawnictwo Naukowe PWN, Warszawa.

Lorek A., 2015, Ustugi ekosystemów w aspekcie zrównoważonego rozwoju obszarów miejskich, Acta Universitatis Lodziensis. Folia Oeconomica, nr 313(2), s. 105.

Nowa Karta Ateńska - Wizja miast XXI wieku, Lizbona, 20.11.2003.

OECD, 2010, Sprawozdanie dotyczące przygotowania Strategii Zielonego Wzrostu, http://www.oecd-ilibrary.org (dostęp: 12.02.2013).

The World Bank, 2012, Inclusive Green Growth: The Pathway to Sustainable Development, DC, Washington.

Ustawa z 17 grudnia 2004 r. o odpowiedzialności za naruszenie dyscypliny finansów publicznych, Dz.U. Nr 14, poz. 114 ze zm. 